\title{
Performance of Bio Concrete by Using Bacillus Pasteurii Bacteria
}

\author{
Gehad A. M. Metwally ${ }^{a^{*}}$, Mohamed Mahdy ${ }^{\mathrm{b}}$, Ahmed H. A. El-Raheem ${ }^{\mathrm{c}}$ \\ ${ }^{a}$ Researcher at Structural Engineering Department, Faculty of Engineering, Mansoura University, Mansoura, Egypt. \\ ${ }^{b}$ Professor and Vice-dean for Students and Education Affairs, Faculty of Engineering, Mansoura University, Mansoura, Egypt. \\ ${ }^{c}$ Professor of a Structural Engineering Department, Faculty of Engineering, Mansoura University, Mansoura, Egypt.
}

Received 08 May 2020; Accepted 09 July 2020

\begin{abstract}
In concrete, cracking is a common phenomenon due to its relatively low tensile strength, which occurs due to external loads and imposed deformations. The main research objective is to create a kind of self-healing concrete by employing mineral producing bacteria Bacillus pasteurii to locate the rift in the most favourable circumstances for autogenous healing to take place. Self-healing concrete containing bacteria has been generated for this study through the application of bacterial self-healing elements as spores and nutrients with different percentages of bacteria ranging from $(10 \%$ $25 \%)$ as a replacement of mixing water is added at the time of pouring. The bacteria influence was observed by Scanning Electron Microscope (SEM) and with Energy Dispersive X-ray Spectrometer. The mechanical properties and durability of a thirty-five mixture were examined. The optimal blending content proportion was 10SF20BC, which showed an increment in compressive strength and flexural strength compared to the control mixture to reach $79.16 \%, 50 \%$ respectively and $24.38 \%$ enhancement in sulfate resistance. The highest percentage of calcium carbonate precipitations was $9.49 \%$ of a weight of mixtures elements, which, in turn, revealed the highest area repair ratewhich was, able to fill the crack with widths leads to $0.80 \mathrm{~mm}$.
\end{abstract}

Keywords: A Live Concrete; Self-recovering Agent; Rifts in Concrete; Abrasion of Steel; Area Repair Rate.

\section{Introduction}

The construction industry in the world has recently testified an enormous development. Concrete as a construction material received widespread use throughout the world during the 20th century. The steady production of Pre-mixed concrete is not only one of those significant indicators of concrete technical success but also totally increases in performance, but we face several novel challenges. The major prevalent issue that there is an increased hazard of rifting owing to Offloading circumstances back to poor Concrete tensile capacity, like cracking, calorific rifting also chemical Responses rifting Because of steel abrasion, Response of alkali-silica, sulfate raid [1]. Cracking increases the likelihood of the hazardous object penetrating the concrete, which negatively affects the integrity of the component since they provide an easy path for the transport of liquids and gases that potentially contain harmful substances. When micro-cracks germinate and strike the reinforcement, not just the concrete itself can be threatened, but also the reinforcement will be rusted when exposed to water, oxygen, and possibly carbon dioxide and chlorides. Micro-cracks are, therefore, precursors to structural failure. Commonly cracks are remedied manually, which is unconvincing since cracks are often difficult to identify, and repair and maintenance costs are high. Self-healing of cracked concrete would, therefore, be extraordinarily beneficial, and research into self-healing concrete has been broadly performed out [2].

\footnotetext{
* Corresponding author: gh4.1992@gmail.com
} 
The evolution of microbial calcium carbonate inside the concrete crack is still questionable and unravelled. The existing works of literature have only focused on the ability to incorporate the bacteria into concrete to have concrete that can remediate itself. From the point of bacterial efficiency in terms of concrete strength, the value of the concrete strength enhancement is almost varied from one to another. Several tests were conducted to measure the strength, durability, and capacity of sealing the cracks without specifying the optimum ratio should be selected to incorporating the microorganisms and concentration of cells [3]. Vempada et al. (2011) observed that an increase of compressive strength of $19.26 \%$ was obtained after $28 \mathrm{~d}$. Their results were attributed to the deposition of both live and dead cells within the cement pores and the precipitation of microbial calcium carbonate inside the pores of the mortar matrix [4]. Concrete strength enhancement of $22 \%$ was also reported with the incorporation of the same bacteria species after $28 \mathrm{~d}$ [5].

While in this study the optimal blending content proportion was identified $(10 \mathrm{SF} 2 \cdot \mathrm{BC})$, which showed an increment in compressive strength and flexural strength compared to the control mixture to reach $79.16 \%$, $50 \%$ respectively, also enhanced the microstructures of concrete with the concentration of $5 \times 10^{9}$ cells $/ \mathrm{ml}^{\text {and } \mathrm{OD}_{600}}$. From another point of view, interesting changes in strength were recorded at an early age. Such finding might be due to the fact that urea, calcium and nutrient were able to find access in the porous concrete to reach the bacteria in order to implement the target biochemical reaction at an early age. This reason was in a good agreement with a previous study reported by Nain et al. (2019) [6].

Self-recovering of Concrete is undoubtedly an ancient and well-identified hypothesis [7]. However, the capacity for crack-healing in most common types of concrete appears to be limited [8]. The microorganisms-induced mineral deposition has been introduced as an effective and natural strategy for enhancing the potential of concrete cracking in recent years [9]. Jonkers and colleagues in their research initially outlined utilizing microorganisms-generated deposition of minerals techniques for the rigorous self-recovering of the concrete fractures, in respect of the operation of healing takes place without human involvement. The specific mechanism of crack-healing is based on concrete matrix-incorporated dormant but viable spores of specific alkali-resistant bacteria, which, after activation by crackingress water, produce inorganic mineral precipitates by conversion of organic precursor compounds. Experimental results showed crack-healing up to $0.64 \mathrm{~mm}$-wide cracks in bacterial concrete but only up to $0.18 \mathrm{~mm}$-wide cracks in control specimens after 100days submersion in water. In the current study, the potential of bacteria to act as a selfhealing agent in concrete, their ability to repair occurring cracks is investigated. A specific group of alkali-resistant spore-forming bacteria related to the genus Bacillus was selected for this purpose shown in Figure 1; however, as bacterial concrete specimens appeared to produce substantially more crack-plugging minerals than control specimens as shown in Figure 2, the potential application of bacterial spores as self-healing agent appears promising [10, 11].

Also in this research, it was pursued to quantify the maximum crack widths that could be healed using photographic images and establish the effect of the formation of the cracking age of bio-concrete specimen on healing efficiency. The healing ratio, according to them, was significantly increased when the artificial crack was developed at an early age. Relatedly, the healing ratio of the cracks was very small when the concrete cracking age was greater than $60 \mathrm{~d}$. Their results were attributed to the decreased number of the bacteria inside the concrete matrix due to the continuous hydration overtime in which the bacteria were crushed by decreasing the concrete pore size over time.

The rate of healing ratio was higher during the first $30 \mathrm{~d}$ compared to the latter two months. This was because the bacteria face challenges over time in the cement matrix. The bacteria lost their space due to hydration reactions over time. Besides, it would be difficult for both nutrient and urea to transport through the target crack in the long term. As was said earlier, both urea and nutrient are necessary for the bacterial activity to grow and produce calcium carbonate respectively. As such, the long-term healing efficacy is still under development and researchers are still devoting considerable efforts to develop better carrier protection for the bacteria from densifying the microstructure of concrete up to date $[12,13]$.

The objectives of the research could be stated as follows:

1. Finding a suitable mixed material proportion. 2. Developing $\mathrm{BcC}$ industry. 3. Evaluating the effect of using the bacteria mechanism in concrete. 4. Assessing the conditions that affect the amount and rate of autogenic healing. Studying the biological and structural behaviour of concrete elements using BC. 


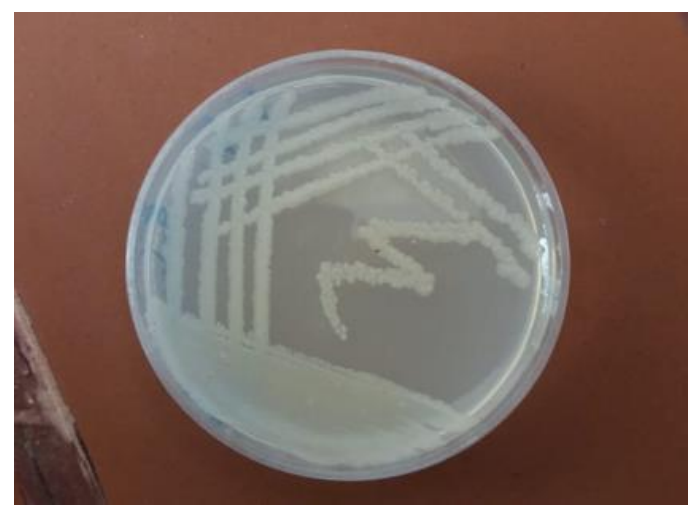

Figure 1. A sample of Bacillus pasteurii

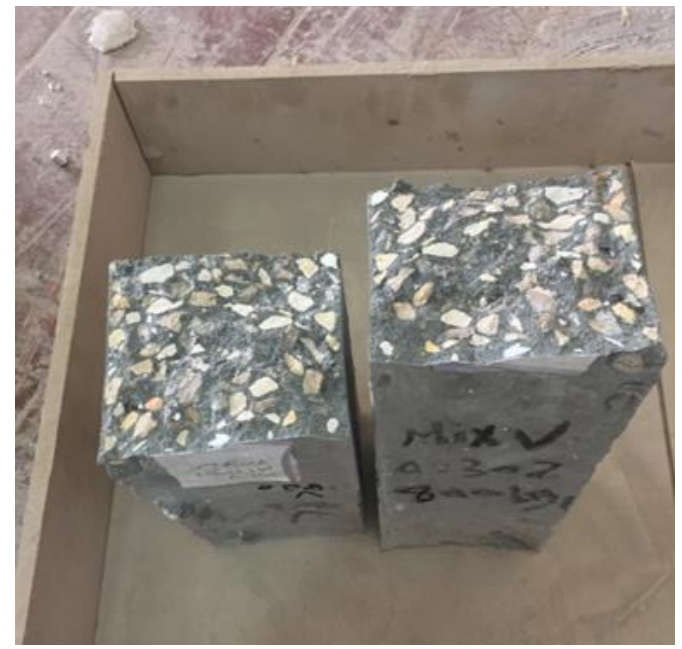

Figure 2. A sample of bacterial concrete

\subsection{Self-Healing Definition}

Developing self-recovering Cementitious combination is a comparatively novel scope of research which, to date, has concentrated on both the indigenous ability of hydrates to heal rifts over time (autogenic) and the synthetic methods of rift maintenance that are human involvement (autonomous) [14]. The purpose of this kind of research is to raise the toughness of the concrete. The genuine self-recovering capacity of concrete, recognized as Autogenous healing, can be visualized in many ancient structures that have existed for such long periods with limited treatment. Rifts in ancient concrete facilities, namely Roman aqueducts and Gothic churches, have also been shown to a collar as rain mixes with unhydrated cement clinkers in cracks. Three major procedures of self- healing, as demonstrated by Joseph (2008) are (i) Cement dentifrice bulge and hydration.; (ii) deposition of carbonate crystals of calcium and; (iii) obstruction of stream routes related to precipitation of water impurities or mobility of concrete segments which separated during the cracking phase [15]. In recent years, several scholars have examined different situations, which affect the amount and level of autogenic healing. Apart from that, it was noted that the initial healing process was continuous hydration [16].

\subsection{Bacteria as a Solution (Healing- Agent)}

Microorganisms-based auto-healing concrete (Bacillus pasteurii) was introduced in this research by the incorporation of a bacterial self-healing compound that has the potential to increase self-healing efficiency, mainly due to bacteria-induced mineral deposition. Precipitation generated on the crack surface of the concrete paste specimens was investigated using the Scanning Electron Microscope (SEM). Moreover, the influence of crack width with curing ways. The results show that the microbial self-healing agent could be used to achieve the goal of concrete crack selfhealing depended on many factors. The deposition shaped on the rift surface was calcite that showed up to be lamellar, near to packing morphology. 


\section{Materials and Methods}

A total of thirty-five (35) batches of 7 mixtures with varied (w/c) ratio were designed. Every five batches were identical in composition and proportions, except for the inclusion of bacteria. The first batch of each mixture without bacteria is regarded as the control mix. All mixtures were designed by using the absolute volume method. The study mixtures binder content was $250 \mathrm{~kg} / \mathrm{m}^{3}, 450 \mathrm{~kg} / \mathrm{m}^{3}$ and $475 \mathrm{~kg} / \mathrm{m}^{3}$. The Experimental program was conducted in four stages all were:

- Stage 1: Design mixtures, processing of sample moulds and preparation of Bacteria;

- Stage 2: Experimental work was carried out on concrete mixtures by mixing stable proportions of PC and SF with stable (W/C) ratio replaced with Bacillus pasteurii and their cement solution;

- Stage 3: Experimental work was carried out on concrete mixtures by mixing stable proportions of PC and SF with various (W/C) ratio replaced with different ratio of Bacillus pasteurii and their cement solution;

- Stage 4: Experimental work was carried out on concrete mixtures by mixing stable proportions of PC, SF and $\mathrm{SP}$ with stable (W/C) ratio replaced with different ratio of Bacillus pasteurii and their cement solution.

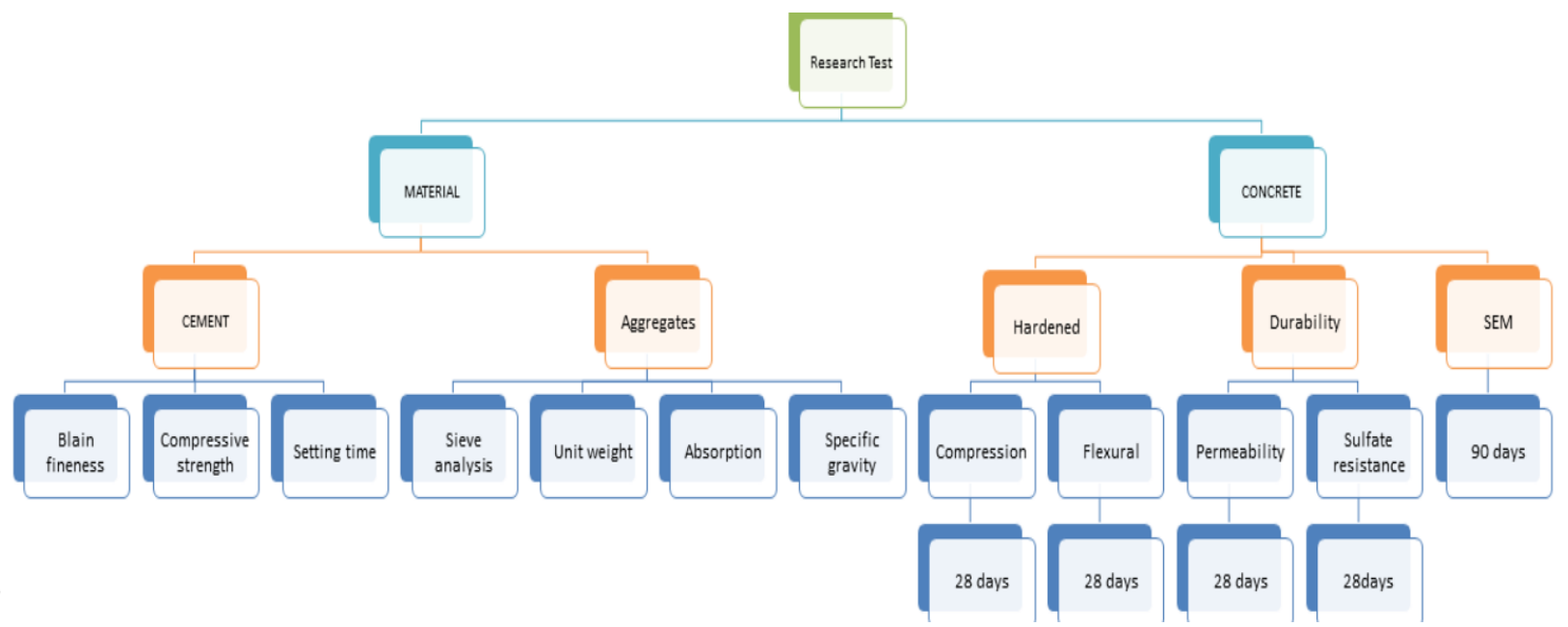

Figure 3. Research test flow chart

\subsection{Preparation of Bacterial Self-healing Factor}

Bacillus pasteurii is sporogenesis alkali-reluctant micro-organisms that have been used for this research; many samples were collected from alkaline lake soil (Wadi Natrun, Egypt). This site is specially chosen because of its relatively high alkalinity and temperature, which is close to the conditions of concrete. Figures 4 to 6 , shows the teamwork during samples collection and the bacterial service life.

\section{A. Isolation and Purification of Bacteria}

1. Assemble equipment such as Petri dishes, flask, and $\mathrm{pH}$-meter.

2. Weigh out 1 gram of your soil and add this to $99 \mathrm{ml}$ of sterile distilled water (1/100 dilution).

3. While still suspended, further dilute the suspension by removing $1 \mathrm{ml}$ micropipette and add it to a test tube containing $9 \mathrm{ml}$ of sterile distilled water(1/10 dilution - 1/1000 total dilution) (Figure 7).

4. Label the agar side of the petri dish with a specified group and specified section numbers.

5. Remove $50 \mathrm{ml}$ of the mixture (a further dilution) and transfer it to the centre of the agar plate.

6. Using sterile techniques, dip a cell spreader in alcohol, hold it in a flame briefly and briefly air cool it then by touching it to the outer edge of the agar. Use this to spread the $50 \mathrm{ml}$ sample evenly around the plate (Figure 8).

7. Repeat steps 4 and 5 to make a second plate.

8. Incubate one plate agar-side up in the $50 \mathrm{ml}$ incubation.

9. Then examine the plates after 24 hours.

10. Photograph the colonies on plates.

11. The colonies were transferred into Petri plates several times to obtained pure single colonies. The pure single 
colonies were morphological properties such as gram staining, shape form, spore-forming, and motility by light microscope.

\section{B. Culture Bacteria - Final Sample Preparation}

The organisms have been grown in a fluid medium found to contain five gm. peptone with three gm yeast extract for each litre of filtered water (Alkalinity= seven), That was properly sanitized at $121{ }^{\circ} \mathrm{C}$ for twenty-five minutes. Forward to immunization on laminar flow; the fluid was brooded at thirty ${ }^{\circ} \mathrm{C}$ on a vibrator at 170 rounds per minute for one day. The bacterial self-recovering factor was made up of cement solution with bacillus pasteurii. The microorganisms have been extracted through Centrifugation of the one-day cultivation and re-distributed in filtered water. The concentration of bacillus pasteurii in solution was $10^{9}$ cells per ml with optical density (OD600).

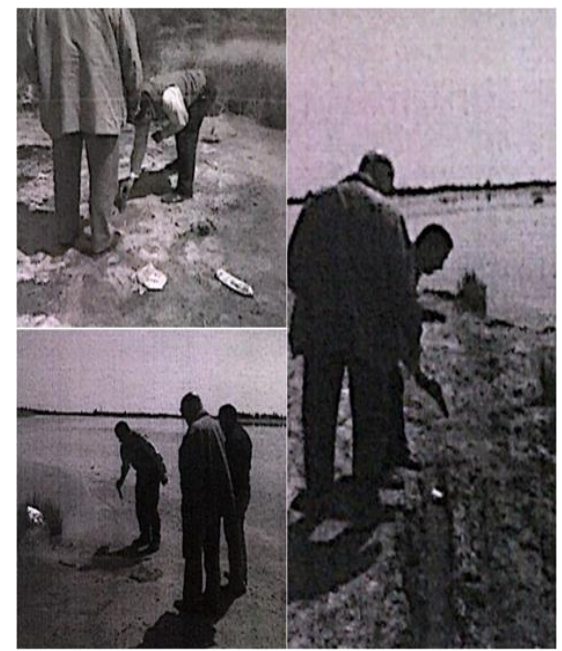

Figure 4. Collection samples from alkaline lake soil Wadi Natrun

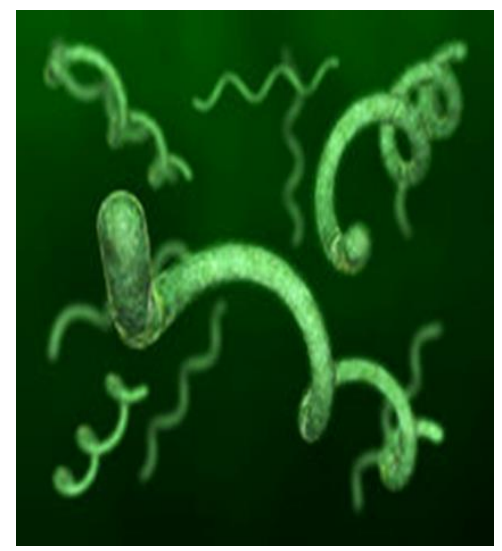

Figure 5. Bacillus pasteurii

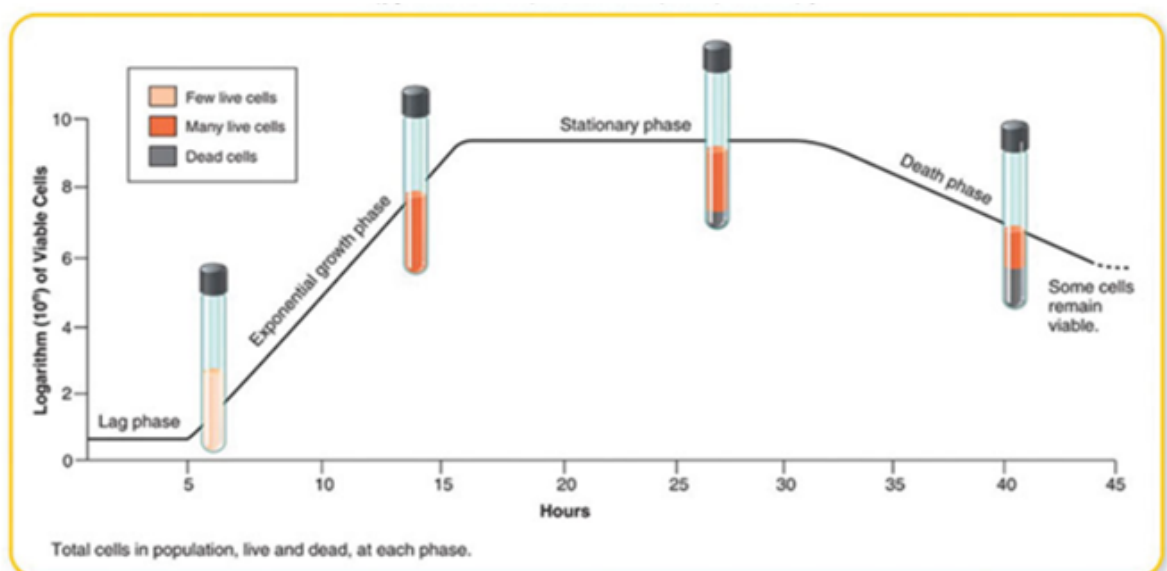

Figure 6. Schematic for Bacterial Growth Life 


\section{Serial dilution}

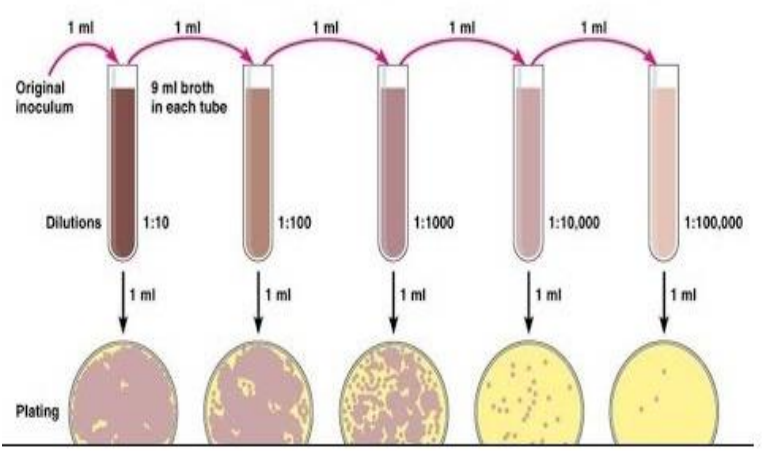

Figure 7. Serial dilution methods

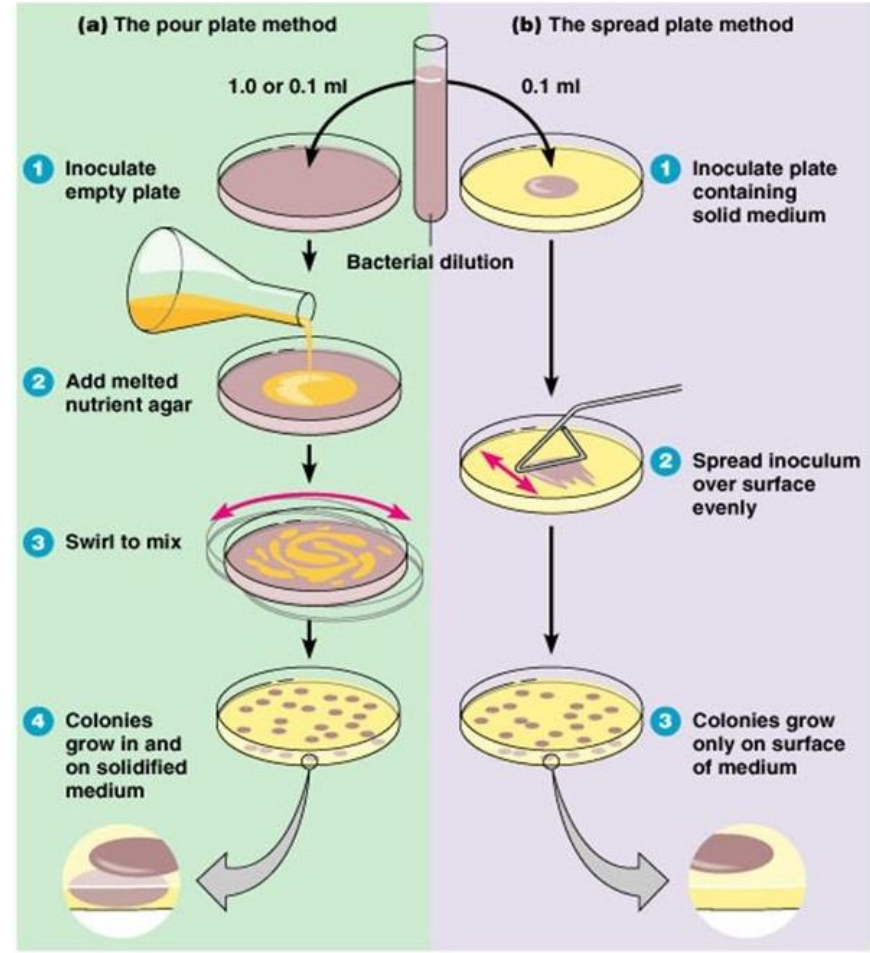

Figure 8. Inoculation Petri plates from serial dilutions

\subsection{Cement Paste Specimens Preparation}

A total of thirty-five (35) batches of 7 mixtures with varied (w/c) ratios were designed. Every five batches were identical in composition and proportions, except for the inclusion of bacteria. The first batch of each mixture without bacteria is regarded as the control mix. All combinations were designed by using the absolute volume method. The study mixtures binder content was $250 \mathrm{~kg} / \mathrm{m}^{3}, 450 \mathrm{~kg} / \mathrm{m}^{3}$, and $475 \mathrm{~kg} / \mathrm{m} 3$. Table 1 presented the study mixture proportion of traditional concrete (TC.), and Table 2 presented study mixture components of High strength (HC.) concrete by weight $\left(\mathrm{kg} / \mathrm{m}^{3}\right)$. Cubic specimens with a dimension of $(15 \times 15 \times 15) \mathrm{cm}$ were cast for permeability test and Sulfate-resistance test, and Cubic specimens with a dimension of $(10 \times 10 \times 10) \mathrm{cm}$ were cast for the compressive strength test. Prismatic specimens with a dimension of $(10 \times 10 \times 50) \mathrm{cm}$ were cast, the first division of them was for flexural strength test, and the others were reloaded using the bending test to simulate the cracks in the site, then cured in order to utilize it for mineralogical composition test: scanning Electronic Microscope (SEM). All specimens were cured in clean tap water at room temperature for 28 days for cube specimens and 28, 90 days for beam specimens.

\subsection{Formation of Synthetic Cracks}

For imitation of the actual state of concrete cracking and decrease the Differences of cracks impact for prismatic specimens, the machine used in bending test was used. Firstly the specimens were loaded on a bending machine test 
with load fixation every time, then during loading Vernier calliper was used to measure the width of the crack until the width required was reached, which varies from 0.1 to $1 \mathrm{~mm}$. The Rifts on beam samples created have been demonstrated in Figure 9.

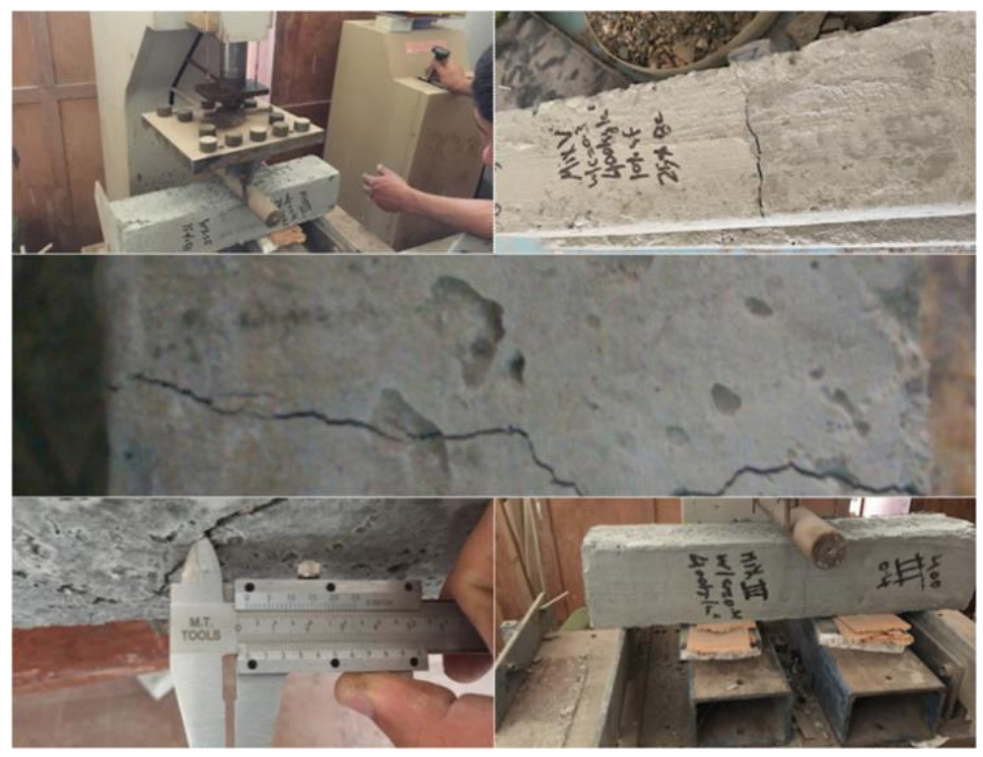

Figure 9. Formation of synthetic cracks

\subsection{Evaluation of Microbial agent Effect on the Self-healing Process}

The cracked prismatic specimens which used during the crack-healing evaluation throughout various crack widths were pulled out after 28 days and 90 days curing using faucet water in Ceramic tub that was exposed to the air throughout the entire healing process. At the same time, oxygen was constantly absorbed into the water. Then the precipitations formed at the surface of the crack of the cement dentifrice samples were examined by using Scanning Electron Microscope (SEM) with EDS (Energy Dispersive Spectrometer) attached to it. Two ways were used to state clearly the capacity of rift repairing. The technique of visual analysis has been used as mentioned above, and the other method was that the prismatic samples were extracted out of the water every several days in order to evaluate, also to register the changes of rifts width via camera with Auto-focus lenses and microscope. Processing of the photo of specimens Surface cracks was rendered pre and post healing. The area repair rate was calculated by measuring the surface area of the cracks before and after healing, according to Equation 1.

The area repair rate $=\frac{\mathrm{Ao}-\mathrm{At}}{\mathrm{Ao}} \times 100 \%$

Where:

$\mathrm{A}_{\mathrm{o}}$ : crack surface area of the original specimen.

$\mathrm{A}_{\mathrm{T}}$ : crack surface area of repaired specimen at time $\mathrm{t}$.

Table 1. Mixing Rate of one $\mathrm{m}^{3}$ cement paste of TC

\begin{tabular}{cccccc}
\hline $\begin{array}{c}\text { Fcu } \\
\left(\mathbf{k g} / \mathbf{c m}^{2}\right)\end{array}$ & $\begin{array}{c}\text { w/c } \\
(\%)\end{array}$ & $\begin{array}{c}\text { Cement } \\
(\mathbf{k g})\end{array}$ & $\begin{array}{c}\text { Water } \\
(\mathbf{l i t})\end{array}$ & $\begin{array}{c}\text { Dolomite } \\
(\mathbf{k g})\end{array}$ & $\begin{array}{c}\text { Sand } \\
(\mathbf{k g})\end{array}$ \\
\hline 250 & 35 & 350 & 122.5 & 1218.56 & 812.4 \\
250 & 40 & 350 & 140 & 1190.73 & 793.82 \\
250 & 50 & 350 & 175 & 1135.08 & 756.72 \\
400 & 35 & 500 & 175 & 1059.37 & 706.25 \\
400 & 40 & 500 & 200 & 1019.62 & 679.74 \\
400 & 50 & 500 & 250 & 940.12 & 626.75 \\
\hline
\end{tabular}

Table 2. Mixing Rate of one $\mathrm{m}^{3}$ cement paste of $\mathrm{HC}$

\begin{tabular}{cccccccc}
\hline $\begin{array}{c}\text { Fcu } \\
\left(\mathbf{k g} / \mathbf{c m}^{2}\right)\end{array}$ & $\begin{array}{c}\text { w/c } \\
(\%)\end{array}$ & $\begin{array}{c}\text { Cement } \\
(\mathbf{k g})\end{array}$ & $\begin{array}{c}\text { Water } \\
(\mathbf{l i t})\end{array}$ & $\begin{array}{c}\text { Dolomite } \\
(\mathbf{k g})\end{array}$ & $\begin{array}{c}\text { Sand } \\
(\mathbf{k g})\end{array}$ & $\begin{array}{c}\text { S.F } \\
(\mathbf{k g})\end{array}$ & $\begin{array}{c}\text { S.P } \\
(\mathbf{k g})\end{array}$ \\
\hline 800 & 28.5 & 475 & 148.91 & 940.12 & 704.45 & 47.50 \\
\hline
\end{tabular}




\subsection{The Mechanism in Bio Concrete}

In order to identify the correct micro-organisms that grow in alkaline atmospheres, they can exist in natural environments such as alkali lakes in Moscow, carbonate-rich soils in desert regions in Spain, and soda lakes in Egypt. Varieties of endolithic bacteria of the gender Bacillus have been found to grow in this high alkaline atmosphere. These bacteria were grown in a flask of water that would then be used as part of the water mixture for the concrete. Various types of bacteria have been inserted into a small cube of concrete. Every concrete cube would have been left for 28 days to be hardened. Then the cube would be crushed, and the remains tested to see if the bacteria had survived. It has been discovered that the only strains of bacteria which were able to sustain were the ones that generated spores relative to plant seeds. They are called bacillus pasteurii. These germs have particularly dense cell membranes which allow them to stay preserved within twenty decades, while still looking for safer germination Surroundings. These ones would have been mobilized once mixes start to break, nutrition is obtainable, and water enters The system; this technique reduces Acid medium related to stronger concrete with high alkalinity till $\mathrm{pH}$ level of ten to eleven whosesoever the germs of bacteria are active as shown in Figure 10. As regards crack-sealing capability, the carbonation process is a process genetically identical to secondary hydration of cement particles. The water is intentionally compelled into the rift, and the components are brisked. The stimulated substrate intern encourages the bacteria to bind with the substrate and to shape a foundation of Calcium carbonate referred to as limestone, as shown in Equation 2.

$\mathrm{Ca}\left(\mathrm{C}_{3} \mathrm{H}_{5} \mathrm{O}_{2}\right)_{2}+7 \mathrm{O}_{2} \rightarrow \mathrm{CaCO}_{3}+5 \mathrm{CO}_{2}+5 \mathrm{H}_{2} \mathrm{O}$
$\mathrm{CO}_{2}+\mathrm{Ca}(\mathrm{OH})_{2} \rightarrow \mathrm{CaCO}_{3}+\mathrm{H}_{2} \mathrm{O}$

The bacteria can thus serve as a nucleation location that promotes The Calcite Deposition that can gradually plug the voids and rifts throughout the concrete. This bacteria mediated calcium carbonate depositions consists of a process of complicated biochemical reactions When part of its metabolism B.Subtilus generates urease, which catalyzes urea to release $\mathrm{CO}_{2}$ and ammonia, resulting in an increase of $\mathrm{pH}$ in the atmosphere where $\mathrm{Ca}^{+2}$ and $\mathrm{CO}_{3}{ }^{-2}$ ion precipitate as $\mathrm{CaCO}_{3}$. This produces calcium carbonate crystals that extend and develop as the bacteria consume the calcium lactate food. The crystals grow until the whole void is covered. Wherever traditional concrete is actually being utilized; alternatively, there is a chance for the use of bacterial self-recovering concrete. The value of the self-healing characteristics attributable is that the permanent and anticipated rifting that occurs in any concrete building, related to the porous design of the matrix, able to be managed, minimized, either fixed, and we do not need man-made intervention. Concrete based bacterial self-recovering often avoids inner reinforcing damage. A process of self-healing concrete has been developed to continually fix any damage caused to and also inside a concrete building. The life cycle of a concrete building was destined to be risen of any volume, form, style, also to compile additional coverage for rebar reinforcement from the components. In this phase, resources have the ability to be preserved, buildings will survive for a lot longer, and the market of concrete all together will turn out to become a lot more practical commodity, effectively reducing the exposure to $\mathrm{CO}_{2}$.

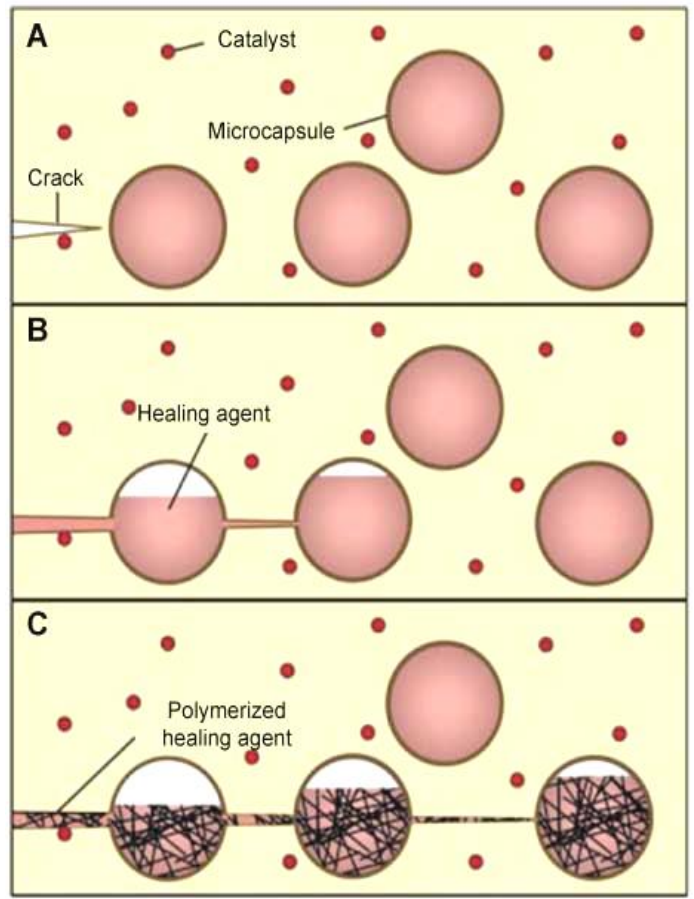

Figure 10. Healing process in concrete( Piyush Sharma, Amity University) 


\subsection{Strength of Bacterial Concrete}

\section{A. Compressive Strength}

The compressive strength test was performed at 28 days in compliance with BS EN 12390-2:2009 standard. One hundred five cubes of $100 \times 100 \times 100 \mathrm{~mm}$ were prepared to be tested at 28 days. All specimens were examined by utilizing a compression hydraulic testing machine with a capacity of 200 tons and accuracy 0.5 tons. The specimen must be aligned in the centre of the machine. The test schedule for compressive strength was performed. The compression strength $(\mathrm{Fc})\left(\right.$ ton $\left./ \mathrm{cm}^{2}\right)$ was calculated according to Equation 3:

$\mathrm{F}_{\mathrm{cu}}=\frac{\mathrm{Pc}}{\mathrm{A}}$

Where:

$\boldsymbol{F}_{c}$ : Compression strength.

$\boldsymbol{P}_{\boldsymbol{c}}$ : The average strength of 3 compression samples result (machine reading (ton)).

A: Cube sample area $\left(\mathrm{cm}^{2}\right)$.

Use of the respiratory bacteria (Bacillus pasteurii) as self-healing factors seems to have a rise in the compressive strength of concrete mixtures containing bacteria compared with control one with ratio varies from 11 to $79 \%$ as shown in Table 3.

\section{B. Flexural Strength}

The Flexural strength test was the most typical. Flexure test is generally used to determine the flexural modulus or flexural strength of a material. A flexure test is more affordable than a tensile test, and test results are slightly different. It was aimed to study the effect of utilizing SCMs and BC on The flexural strength test. Investigating the effect of flexural strength was essential to maintain concrete durability by preventing crack and corrosion. It must be taken into design consideration. The flexural strength test was carried out and complied with BS EN 12390-6:2009 standard after 28 days of curing. The experiment was performed on prismatic samples because of its better accuracy than another sample. Results showed a 50\% improvement in flexural strength compared with the control one.

\subsection{Temperature Sustainability Test of Bacteria}

The B.Subtilis Temperature Sustainability Check was performed at different temperatures degree by Manikandan and Padmavathi (2015) [17]. Findings are included in schedule 4. Tests have shown that bacillus pasteurii was noticed to be vivid at $-3^{\circ} \mathrm{C}-80^{\circ} \mathrm{C}$ elevated temperatures.

Table 3. Compressive strength of bacterial concrete

\begin{tabular}{|c|c|c|c|c|c|c|c|}
\hline \multirow{3}{*}{$\begin{array}{c}\text { Mixture } \\
\text { w/c }\end{array}$} & \multicolumn{7}{|c|}{$\begin{array}{c}\text { Compressive Strength } \\
\left(\mathbf{k g} / \mathrm{cm}^{2}\right)\end{array}$} \\
\hline & \multicolumn{3}{|c|}{$\begin{array}{l}\text { Test time (28days), } \\
\text { Fcu }=250 \mathrm{~kg} / \mathrm{cm}^{2}\end{array}$} & \multicolumn{3}{|c|}{$\begin{array}{l}\text { Test time (28days), } \\
\text { Fcu }=400 \mathrm{~kg} / \mathrm{cm}^{2}\end{array}$} & \multirow{2}{*}{$\begin{array}{c}\begin{array}{c}\text { Test time (28days) } \\
\mathbf{F c u}=\mathbf{8 0 0} \mathbf{~ k g} / \mathbf{c m}^{2}\end{array} \\
0.285\end{array}$} \\
\hline & 0.35 & 0.40 & 0.50 & 0.35 & 0.40 & 0.50 & \\
\hline $\begin{array}{l}\text { Compressive Strength of } \\
\text { traditional Concrete } \\
\text { Cubes, } \mathrm{kg} / \mathrm{cm}^{2}\end{array}$ & 250 & 240 & 230 & 270 & 250 & 240 & 840 \\
\hline $\begin{array}{c}\text { Compressive Strength of } \\
\text { Bacillus Pasteurii Concrete } \\
\text { Cubes, } \mathrm{kg} / \mathrm{cm}^{2}\end{array}$ & 320 & 430 & 296 & 300 & 280 & 278 & 900 \\
\hline$\%$ Increase in Strength & $28 \%$ & $79.16 \%$ & $28.69 \%$ & $11.11 \%$ & $12 \%$ & $15.83 \%$ & $7.14 \%$ \\
\hline
\end{tabular}


Table 4. Examination of Temperature Sustainability with Bacillus pasteurii Bacteria

\begin{tabular}{cc}
\hline Temperature $\left({ }^{\circ} \mathbf{C}\right)$ & Bacteria Condition \\
\hline 10 & Alive \\
20 & Alive \\
30 & Alive \\
40 & Alive \\
50 & Alive \\
60 & Alive \\
70 & Alive \\
80 & Alive \\
90 & Dead \\
\hline
\end{tabular}

\section{Outcomes and Debates}

\subsection{Rift- recovering Estimation Below Various Rift Width}

Figure 11 displays crack pictures with a breadth of $0.40 \mathrm{~mm}$ in samples with a self-healing factor during various healing phases. It can be visualized that the rifts were repaired by calcite depositions. The repairing performance of the various width rifts appeared remarkable. Following 28 days of inundation in tap water, the crack with a width of 0.40 $\mathrm{mm}$ was almost completely healed, while the rift with a width equal $0.8 \mathrm{~mm}$ was poorly healed.

Analysis in microscopy of the deposition at the cracking outside of the concrete samples was performed. The SEM picture of crack surface depositions is shown in Figure 12. The crystal tends to be lamellar near packing morphology. The composition of product study using EDS reveals that precipitation at the crack surface was a Combining of carbon, oxygen, and calcium molecules, as shown in Figure 13. Then the region repair rate of samples of various crack width was determined on the basis of specific repair period before and after healing using Vernier calliper as shown in Figure 14 and Table 5.

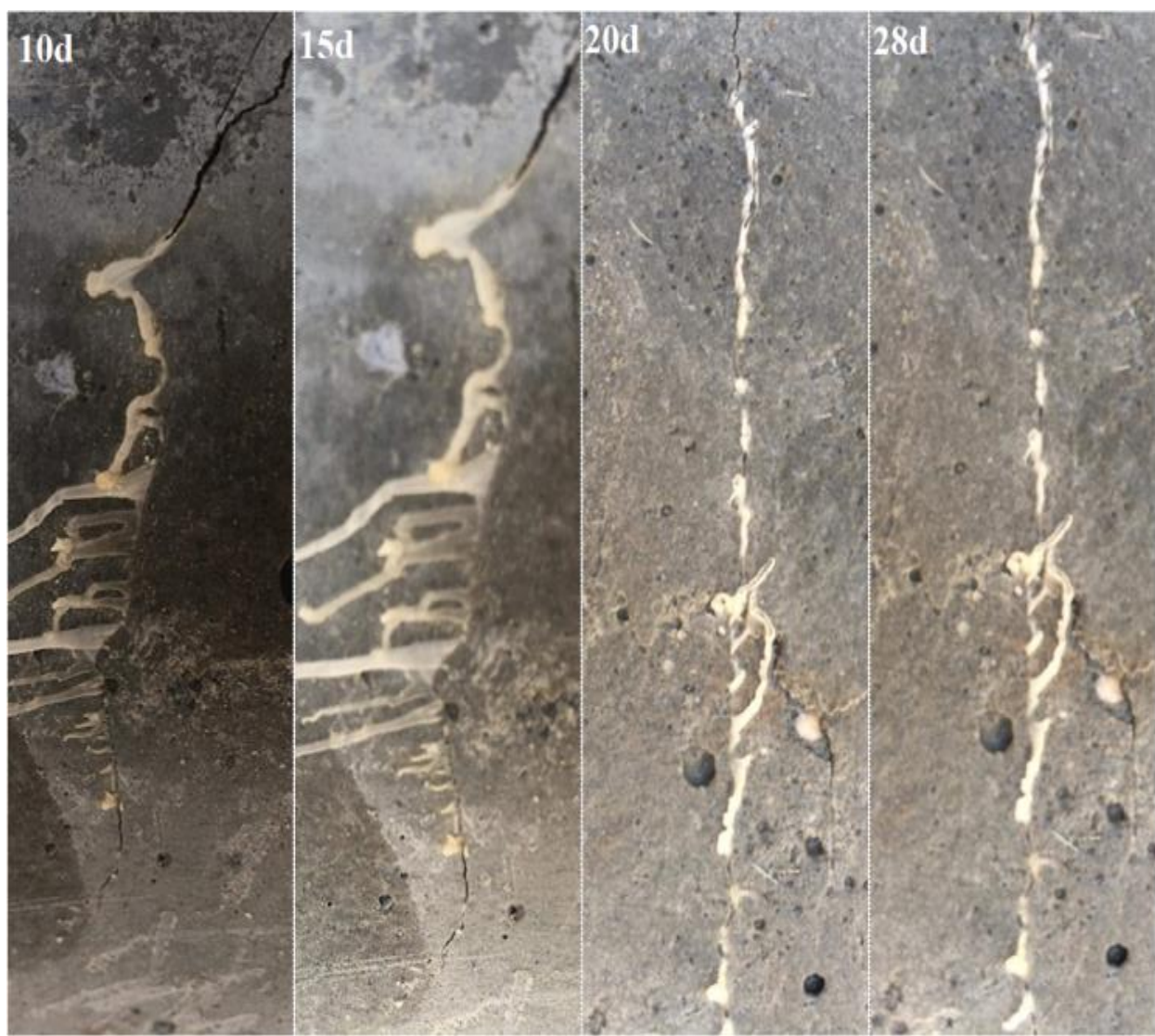

Figure 11. The surface image of a specimen with an average width of crack $0.40 \mathrm{~mm}$ 


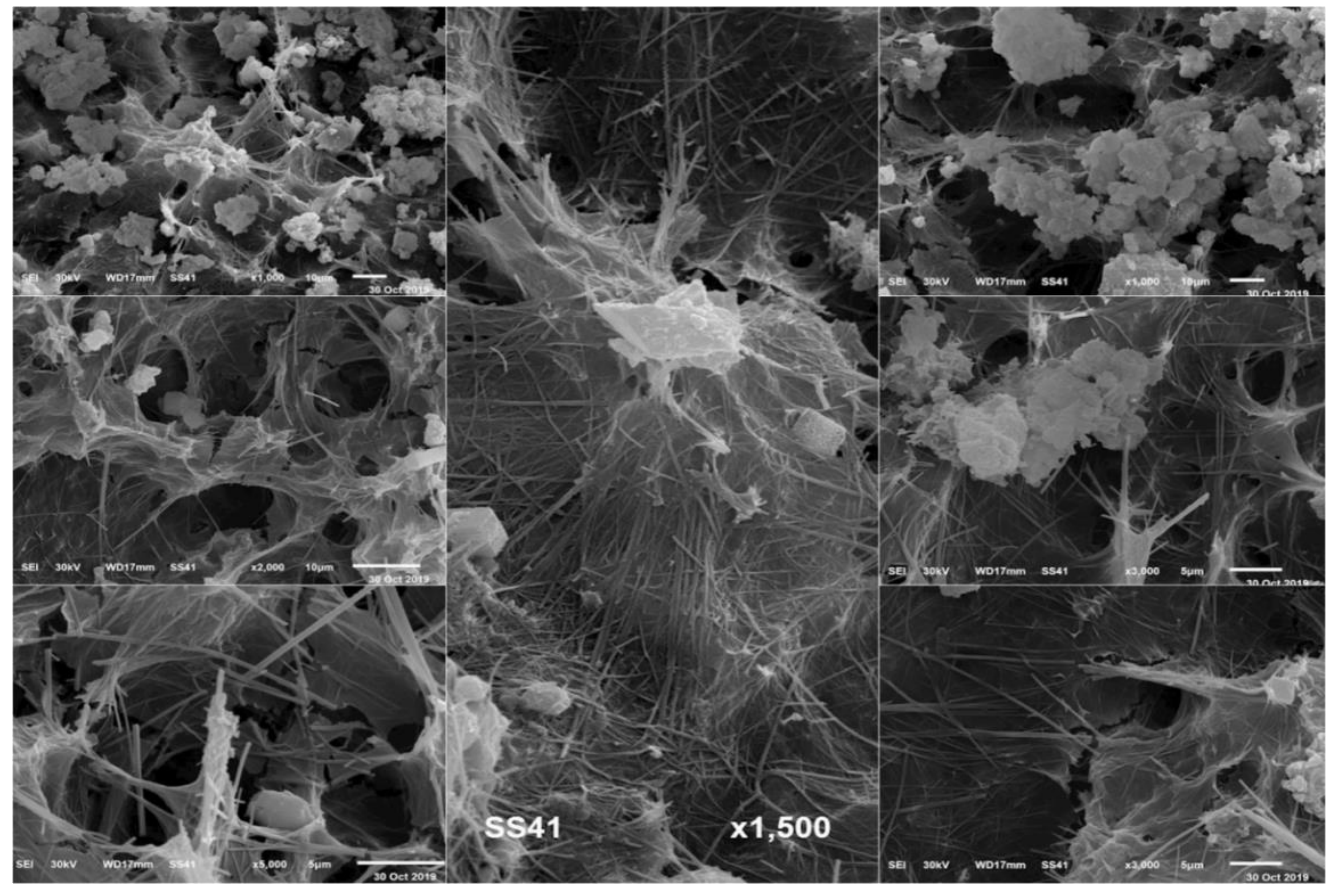

Figure 12. SEM images of participation at crack surface $\left(\mathrm{Fcu}=250 \mathrm{~kg} / \mathrm{cm}^{2}, w / \mathrm{c}=0.50, \mathrm{MII}\right)$

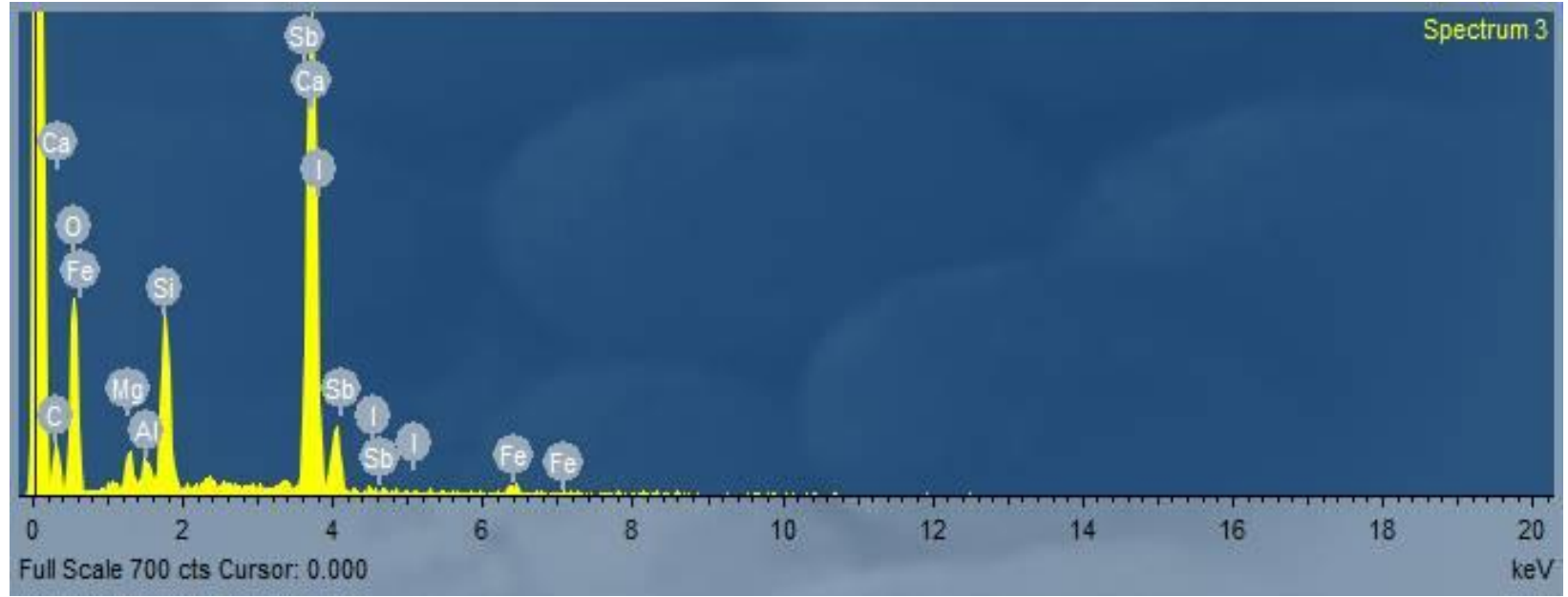

Figure 13. EDSS spectrum of deposition at the crack surface

Table 5. Area repair rate data of specimens of various rift width following varying repair periods.

\begin{tabular}{|c|c|c|c|c|c|c|c|c|c|}
\hline \multirow{2}{*}{ Crack width } & \multirow{2}{*}{ Ao $\left(\mathbf{m m}^{2}\right)$} & \multicolumn{4}{|c|}{ At $\left(\mathbf{m m}^{2}\right)$} & \multicolumn{4}{|c|}{ Area repair rate $\%$} \\
\hline & & Od & $10 d$ & $20 \mathrm{~d}$ & $28 d$ & Od & $10 d$ & $20 \mathrm{~d}$ & $28 d$ \\
\hline 0.1 & 10 & 10 & 0 & 0 & 0 & 0 & $100 \%$ & $100 \%$ & $100 \%$ \\
\hline 0.2 & 20 & 20 & 3 & 2 & 0 & 0 & $85 \%$ & $90 \%$ & $100 \%$ \\
\hline 0.3 & 30 & 30 & 12 & 6 & 4.8 & 0 & $60 \%$ & $80 \%$ & $84 \%$ \\
\hline 0.4 & 40 & 40 & 24 & 16 & 14 & 0 & $40 \%$ & $60 \%$ & $65 \%$ \\
\hline 0.5 & 50 & 50 & 29.5 & 21.5 & 19.5 & 0 & $41 \%$ & $57 \%$ & $61 \%$ \\
\hline 0.6 & 60 & 60 & 37.8 & 34.8 & 32.4 & 0 & $37 \%$ & $42 \%$ & $46 \%$ \\
\hline 0.7 & 70 & 70 & 51.1 & 48.3 & 42 & 0 & $27 \%$ & $31 \%$ & $40 \%$ \\
\hline 0.8 & 80 & 80 & 64 & 57.6 & 50.4 & 0 & $20 \%$ & $28 \%$ & $37 \%$ \\
\hline 0.9 & 90 & 90 & 81 & 81 & 81 & 0 & $10 \%$ & $10 \%$ & $10 \%$ \\
\hline 1 & 100 & 100 & 100 & 100 & 100 & 0 & $0 \%$ & $0 \%$ & $0 \%$ \\
\hline
\end{tabular}




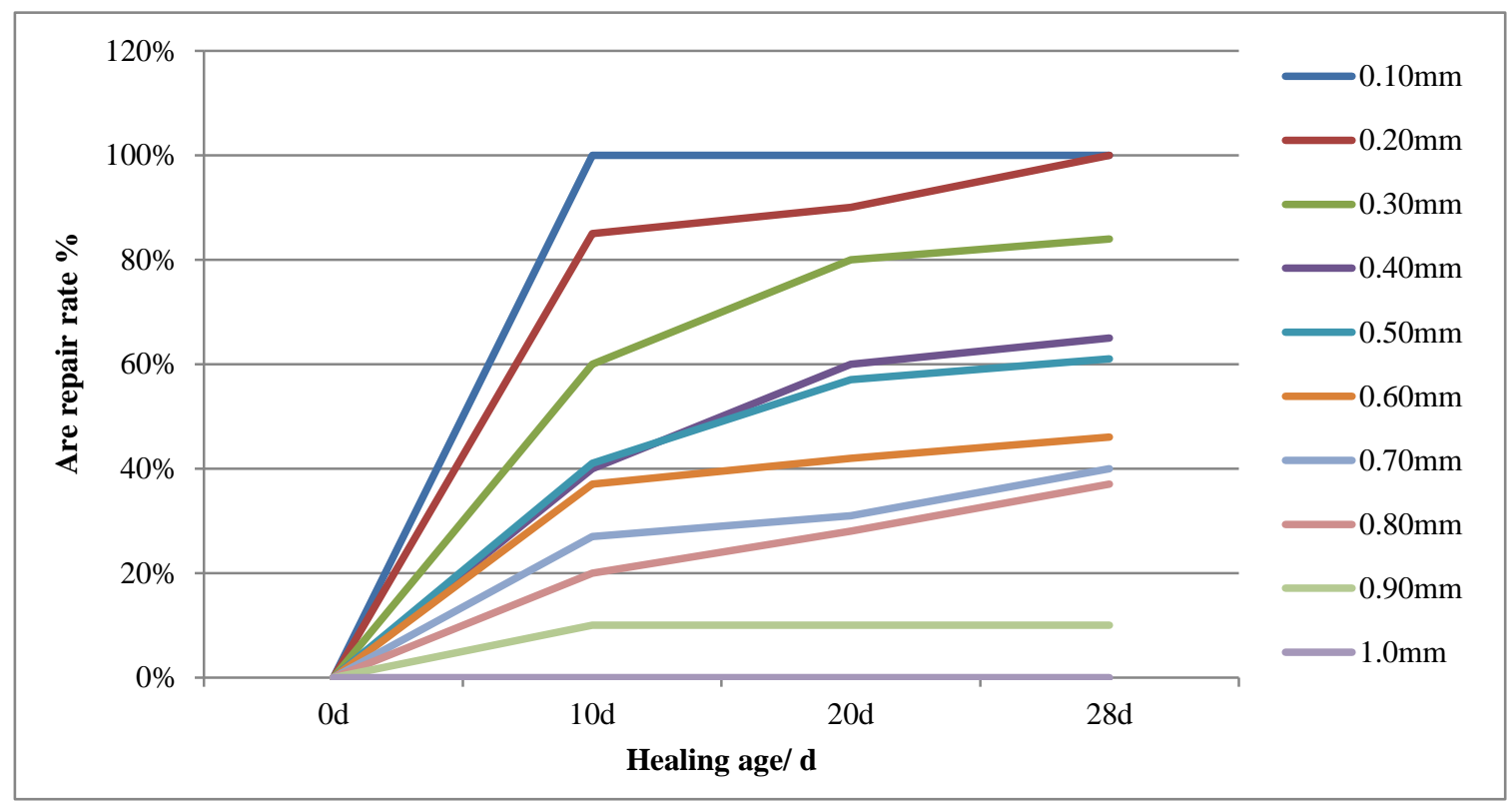

Figure 14. The repair ratio of samples related to various rift widths following different repair period

From Figure 14, it can be seen that the crack was more difficult to repair due to an increase in the average crack width and a reduction in the repair capacity of the bacterial repair factor. The remedy effect for a typical rift width varies from 0.1 to $0.3 \mathrm{~mm}$ was too significant, and the rift healing ratio was varied from eighty-five percent to one hundred percent after Twenty days of maintenance. The rift fixation effect also was perfect for an average rift width varies from 0.3 to $0.5 \mathrm{~mm}$, and the rift healing amount was about 50-70 percent after Twenty days of maintenance. Nevertheless, the repair capacity of the bacterial repair factor was constrained to samples with a rift reach to $0.8 \mathrm{~mm}$ width, with accompanying the rift repair ratio was less than $30 \%$.

The mentioned process may be described in 2 forms, on the basis of an assumption of bacterial mineral deposits utilized in concrete self-recovering. Cement solution with bacteria has been applied to the concrete as a self-healing component. Once cracks develop, bacteria are stimulated, and cracks are filled by white deposition. Calcium carbonate deposition is generated by the metabolic transformation of the respiration substrate.

Calcium carbonate precipitation begins first in the bacterium location, then steadily increases and finally completely repairs the rift in the mortar sample. Further calcite deposition is required for rifts with a wider width to fully fill the rift. With a regular volume of repair agents, it becomes harder to repair larger cracks. And from the other hand, the width of the crack is massive. The repair factor and production of mineral deposition distributed more easily to the exterior water layer, leading to a loss of the repair agent, resulting in a partial waste repair agent and a poor repair effect.

Ghosh and Tran (2014) observed the increase in the compressive strength of concrete mixtures (25\%) at $28_{\text {th }}$ day in the range of $10^{5}$ cells $/ \mathrm{ml}$ to the mixing water [18]. Ramachandran et al. (2001) noticed the use of aerobic microorganisms as self-healing agents have shown $18 \%$ improvement in the compressive strength of concrete mixtures, however, in this study MIV results with $20 \%$ replacement of bacteria showed an increment in compressive strength compared to the control mixture to reach $79.16 \%$ at $28_{\text {th }}$ day in the range of $5 \times 10^{9}$ cells $/ \mathrm{ml}$ to the mixing water, which was the highest value among all combinations [19-21].

\subsection{Benefits of Microbial Concrete}

1. Bacterial concrete assists in rift healing.

2. Enhancement of compressive strength

3. Improved protection with a freeze-thaw crack decrease.

4. Minimization of the permeability of concrete.

5. Significant decrease of rust of concrete containing rebars.

Concrete production adds to approximately $5 \%$ of the Emissions of carbon dioxide that cause global warming. Bioconcrete encourages sustainability by promoting the rainwater filtration, preserving $\mathrm{pH}$ ratios within the optimal range and softening of rainwater. Bio-concrete is a renewable alternative that may extend the existence of current buildings. As per strength, compared to normal concrete, the bio-concrete is durable, has lower permeability as well as provides 
improved resistance to abrasion. Economically, as the structure of bio-concrete carries self-healing capabilities, the substance will reduce the long-term maintenance expenses of the building.

\subsection{Problems of Bacterial Concrete}

1. The expense of concrete containing bacteria is double that of normal concrete, as the extraction of calcium lactate from materials is more costly.

2. In some environmental conditions, the productivity of bacteria is not healthy.

3. Till now, we haven't ISS code for the construction of a mixture of concrete of bacteria.

Cost of bacterial concrete is 7 to $28 \%$ more than the conventional one; however, it can help to reduce the cost of repairing afterwards, which normally cause more than installing the bacterial concrete. Bacteria growing in concrete are not good for human health and atmosphere. Its usage needs to be limited to the structure does not involve near to human life, such as houses or apartments. There are no standard designs in practice for the bacterial concrete design mix to obtain the optimum performance. The suitable amount of bacteria and its type is always changing depending on the applications. The methods to investigate involving the studies related to calcite precipitation are always costly because it involves techniques like Scanning Electron Microscopy (SEM) which is costly and requires skilled personnel to run the tests [22].

\section{Conclusion}

Bacteria considered being alkali immune, which grows in inherent surroundings distinguished by comparatively elevated $\mathrm{pH}$, varies from 10 to 11 . Furthermore, this mentioned progeny may generate germs that restful the cells with robust cell walls that shield cells from severe surrounding mechanical and chemical Fatigue. As a consequence, bacillus pasteurii can obtain the capacity to resist elevated inner concrete $\mathrm{pH}$ rates (12 to 13 for conventional concrete) and continue to survive for a longer period. This is assumed to know that the bacteria immobilized germs can able to fill rifts through Biological-mineral development following they have been resurrected by water and Growth of nutrients reaching newly formed rifts. Compressive strength test results observed improvement by utilizing the mixture of SCMs with a self-healing agent (Bacillus pasteurii). The compressive strength development relied on a type of utilized materials, utilized materials mixing ratio and water to binder ratio, MIV results showed an increment in compressive strength compared to the control mixture to reach $79.16 \%(\mathrm{w} / \mathrm{c}=0.40$, $\left.\mathrm{Fcu}=250 \mathrm{~kg} / \mathrm{cm}^{2}\right)$, where MV achieved enhancement to $11.11 \%$ related to its control blend $(\mathrm{w} / \mathrm{c}=0.35, \mathrm{Fcu}=400$ $\mathrm{kg} / \mathrm{cm}^{2}$ ), while the high strength concrete obtained raising to $7.14 \%$ related to control mixture (w/c $=0.302, F c u=800$ $\mathrm{kg} / \mathrm{cm}^{2}$ ). Flexural strength was also improved within the range of (15 to 20) \% replacement of blended water. MV results showed an increment compared to the control mixture to reach $400.32 \%\left(\mathrm{w} / \mathrm{c}=0.40, \mathrm{Fcu}=250 \mathrm{~kg} / \mathrm{cm}^{2}\right)$, where MIV achieved enhancement to $142.82 \%$ related to its control blend $\left(\mathrm{w} / \mathrm{c}=0.40, \quad \mathrm{Fcu}=400 \mathrm{~kg} / \mathrm{cm}^{2}\right)$, while the high strength concrete mixture obtained rising in flexural strength to $53.14 \%$ related to control mixture $\left(\mathrm{w} / \mathrm{c}=0.302, \mathrm{Fcu}=800 \mathrm{~kg} / \mathrm{cm}^{2}\right)$. The optimum mixing material ratio was $10 \mathrm{SF} 20 \mathrm{BC}$, which displayed the highest percentage of calcium carbonate precipitations $9.49 \%$ of aweight of mixtures element in the range of $5 \times 10^{9}$ cells $/ \mathrm{ml}$ to the mixing water. The best crack width could be healed was varied between 0.1-0.60 mm, and after that, the concentration of cells in bacteria should be increased as shown in MIV.

\section{Conflicts of Interest}

The authors declare no conflict of interest.

\section{References}

[1] Li, Victor C, Yun Mook Lim, and Yin-Wen Chan. "Feasibility Study of a Passive Smart Self-Healing Cementitious Composite." Composites Part B: Engineering 29, no. 6 (November 1998): 819-827. doi:10.1016/s1359-8368(98)00034-1.

[2] Yang, Yingzi, Michael D. Lepech, En-Hua Yang, and Victor C. Li. "Autogenous Healing of Engineered Cementitious Composites Under Wet-dry Cycles." Cement and Concrete Research 39, no. 5 (May 2009): 382-390. doi:10.1016/j.cemconres.2009.01.013.

[3] Amer Algaifi, Hassan, Suhaimi Abu Bakar, Abdul Rahman Mohd. Sam, Mohammad Ismail, Ahmad Razin Zainal Abidin, Shafinaz Shahir, and Wahid Ali Hamood Altowayti. "Insight into the Role of Microbial Calcium Carbonate and the Factors Involved in Self-Healing Concrete." Construction and Building Materials 254 (September 2020): 119258. doi:10.1016/j.conbuildmat.2020.119258.

[4] Vempada, Srinivasa Reddy, S. Sunil Pratap Reddy, MV Seshagiri Rao, and Ch Sasikala. "Strength enhancement of cement mortar using microorganisms-an experimental study." Int J Earth Sci Eng 4 (2011): 933-936. 
[5] Afifudin, Habulat, Mohd Saman Hamidah, Hussain Noor Hana, and Kartini Kamaruddin. "Microorganism Precipitation in Enhancing Concrete Properties." Applied Mechanics and Materials 99-100 (September 2011): 1157-1165. doi:10.4028/www.scientific.net/amm.99-100.1157.

[6] Nain, Nidhi, R. Surabhi, N.V. Yathish, V. Krishnamurthy, T. Deepa, and Seema Tharannum. "Enhancement in Strength Parameters of Concrete by Application of Bacillus Bacteria." Construction and Building Materials 202 (March 2019): 904-908. doi:10.1016/j.conbuildmat.2019.01.059.

[7] Jacobsen, Stefan, and Erik J. Sellevold. "Self-Healing of High Strength Concrete after Deterioration by Freeze/thaw." Cement and Concrete Research 26, no. 1 (January 1996): 55-62. doi:10.1016/0008-8846(95)00179-4.

[8] Reinhardt, Hans-Wolf, and Martin Jooss. "Permeability and Self-Healing of Cracked Concrete as a Function of Temperature and Crack Width." Cement and Concrete Research 33, no. 7 (July 2003): 981-985. doi:10.1016/s0008-8846(02)01099-2.

[9] Bang, S. S., J. J. Lippert, U. Yerra, S. Mulukutla, and V. Ramakrishnan. "Microbial Calcite, a Bio-Based Smart Nanomaterial in Concrete Remediation." International Journal of Smart and Nano Materials 1, no. 1 (February 17, 2010): $28-39$. doi:10.1080/19475411003593451.

[10] Jonkers, H. M., and E. Schlangen. "Towards a sustainable bacterially-mediated self healing concrete." In Proceedings of 2nd International Conference on Self-Healing Materials, Chicago. (2009).

[11] Jonkers, Henk M. "Self Healing Concrete: A Biological Approach.” Self Healing Materials (2007): 195-204. doi:10.1007/9781-4020-6250-6_9.

[12] Su, Yilin, Jianhang Feng, Peng Jin, and Chunxiang Qian. "Influence of Bacterial Self-Healing Agent on Early Age Performance of Cement-Based Materials." Construction and Building Materials 218 (September 2019): 224-234. doi:10.1016/j.conbuildmat.2019.05.077.

[13] Jiang, Lu, Guanhua Jia, Chen Jiang, and Zhu Li. "Sugar-Coated Expanded Perlite as a Bacterial Carrier for Crack-Healing Concrete Applications." Construction and Building Materials 232 (January 2020): 117222. doi:10.1016/j.conbuildmat.2019.117222.

[14] Schlangen, E. "Self-healing phenomena in cement-based materials." RILEM (2005).

[15] Joseph, C., "Experimental and Numerical Study of the Fracture and Self-Healing of Cementitious Materials" PhD thesis: Cardiff University, (2008).

[16] Ter Heide, N., E. Schlangen, and K. Van Breugel. "Experimental study of crack healing of early age cracks." In Proceedings Knud Højgaard conference on Advanced Cement-Based Materials, Technical University of Denmark. (2005).

[17] Manikandan, A. T., and A. Padmavathi. "An experimental investigation on improvement of concrete serviceability by using bacterial mineral precipitation." International Journal of Research and Scientific Innovation (IJRSI) 2, no. 3 (2015): 48.

[18] Ghosh, Pratanu, and Quang Tran. "Correlation Between Bulk and Surface Resistivity of Concrete.” International Journal of Concrete Structures and Materials 9, no. 1 (November 21, 2014): 119-132. doi:10.1007/s40069-014-0094-z.

[19] Biglari, Moein, Amirhosein Sheykh Azami, Ali Kahidan, Ehsan Ghafari, and Mohammad Ali Ghasemi. "Investigating the Effects of Cement Type and W/C Ratio on the Concrete Corrosion Using the Electrical Resistance Assessment Method." Civil Engineering Journal 4, no. 8 (August 31, 2018): 1897. doi:10.28991/cej-03091124.

[20] Ramachandran, Santhosh K., V. Ramakrishnan, and Sookie S. Bang. "Remediation of concrete using micro-organisms." ACI Materials Journal-American Concrete Institute 98, no. 1 (2001): 3-9. doi:10.14359/10154.

[21] V. Ramakrishnan, S. S. Bang, K.S. Deo, "A novel The technique for repairing cracks "high-performance concrete using bacteria, Proc. Int. Conf. on High-Performance High Strength Concrete. "Perth, Australia, (1998): 597-618.

[22] Andalib, Ramin, Muhd Zaimi Abd Majid, Mohd Warid Hussin, Mohanadoss Ponraj, Ali Keyvanfar, Jahangir Mirza, and HanSeung Lee. "Optimum Concentration of Bacillus Megaterium for Strengthening Structural Concrete." Construction and Building Materials 118 (August 2016): 180-193. doi:10.1016/j.conbuildmat.2016.04.142. 